\title{
Recrystallization Behavior of CP Ti Welds by Rolling
}

\author{
압연에 의한 $\mathrm{CP} \mathrm{Ti}$ 용접부 재결정 거동 연구 \\ Byoung-Hyun Yoon*, Ji-Yeon Shim**, and Bong-Yong Kang** \\ *Rapidly Solidified Materials Research Center, Chungnam National Univ., Daejeon, 34134, Korea \\ **Korea Institute of Industrial Technology, Jeonju, 54845, Korea
}

†Corresponding author: byoon007@naver.com

(Received October 26, 2021; Revised November 24, 2021; Accepted December 3, 2021)

\begin{abstract}
Electrolytic copper foil is a thin copper film material manufactured by electroplating and is mainly used as a circuit material to transmit electrical signals in printed circuit boards of electronic products such as TVs, PCs, and smartphones. Recently, it has been widely used as a negative current collector for lithium-ion batteries, which is essential for mobile IT and electric vehicles. The electrodeposited drum material is composed of CP Ti, which exhibits corrosion resistance and has a light weight, and welding is essential for processing in the form of a drum. Therefore, when the microstructures of the base metal and the welded part differ, these differences are reflected in the surface of the copper foil, which results in poor quality. Therefore, in this study, a welding process that required a low heat input while minimizing the size of the weld was used, and the change in the grain size was studied through plastic deformation and recrystallization heat treatment of the weld structure. Following the recrystallization heat treatment after the rolling of the plasma welded specimen, it was found that the calculation results of the recrystallization heat treatment were consistent with the actual conditions of the heat treatment, and the microstructure of the weld metal became finer as the rolling reduction rate increased.
\end{abstract}

Key Words: Electrolytic copper foil, Drum, CP Ti, Welding, Grain size, Recrystallization

\section{Introduction}

The electrolytic copper foil is a thin copper film fabricated through an electroplating process, which is mainly used as circuit components that transmit electrical signals in printed circuit boards of electronic products such as television, personal computer, and smartphones. Recently, their demand is increasing as the cathode current collector material, which is essentially applied in lithium-ion batteries of mobile information technology (IT) and electric vehicles. The electrolytic copper foil is fabricated with the electroplating method, using the equipment composed of a cathode (titanium), anode (titanium), and busbar (copper). This rocess consists of creating a copper sulfate solution for fabricating the copper foil by melting highly pure cop- per into a sulfuric acid solution, electroplating the copper ions from the copper sulfate solution to a largescale Ti drum (cathode) in the electrolyzer, and exfoliating to create a rolled product. The commercially pure $(\mathrm{CP}) \mathrm{Ti}$ is used as an electroplating drum material by considering the corrosion resistance, lightweightness, and detachability where processing it into a drum shape requires welding. However, a microstructural variation in the base material and the weld zone results in a defective product due to the transcription to the copper foil surface. Thus, microstructural adjustment is necessary to have a weld zone structure similar to the base material structure. $\mathrm{Kang}^{1)}$ reported that the soldering process of the $\mathrm{CP}$ Ti material during the friction stir welding had been achieved at a $\beta$-transformation temperature or below and no phase transformation occurred in the $\mathrm{CP} \mathrm{Ti}$, while phase transformation oc- 
curred in the Ti-6Al-4V alloy because the processing temperature reached the $\beta$-transformation temperature or above. According to Moon ${ }^{2)}$, the MC (M: V and/or $\mathrm{Nb}$ ) carbide was extracted at the transgranular zone and crystal grain boundary in the welding of the austenitic Fe-30Mn-9Al-0.9C (wt\%), in which $\mathrm{Nb}$ and $\mathrm{V}$ were added, and crystal grain boundary growth inhibition effect was observed at the heat-affected zone. $\operatorname{Tan}^{3)}$ performed hot rolling of the CP Ti material in the 600 $800^{\circ} \mathrm{C}$ range and air cooling thereafter. Consequently, the recrystallization behavior of the crystal grain was observed. Hayashi et al. ${ }^{4)}$ also performed hot rolling of $\mathrm{CP} \mathrm{Ti}$ at $600-800^{\circ} \mathrm{C}$ according to the varying reduction rate, which showed variations in rolled structure such as the generation of a twin crystal due to the forming process generated during rolling. Hayashi et al. ${ }^{4)}$ reported that the structure became finer due to recrystallization during the cooling process and that the structure transformed due to static recrystallization according to the temperature and reduction rate. In this study, a low heat input welding process, which could minimize the weld zone size, was utilized. Furthermore, the variation in grain size was studied through the forming process of the weld zone structure and recrystallization annealing

\section{Materials and Experimental Methods}

\subsection{Materials}

The material used in this study was a $9-\mathrm{mm}$ grade 1 CP Ti, and the analysis results of its chemical substances and mechanical properties are summarized in Table 1 . As a grade 1 material containing $0.025 \mathrm{wt} \%$ $\mathrm{Fe}$, the elongation rate was $39 \%$ and tensile strength $324 \mathrm{MPa}$.

Fig. 1 presents an image of the microstructure of the material used, in which grain size measurement results revealed that their degree was at level No.9.9 of the American Society for Testing and Materials (ASTM).

\subsection{Welding process}

The welding of the Ti material proceeded in two parts.

Table 1 The materials used in this study

$(\mathrm{wt} \%)$

\begin{tabular}{|c|c|c|c|c|c|}
\hline $\mathrm{Fe}$ & $\mathrm{C}$ & $\mathrm{N}$ & $\mathrm{O}$ & $\mathrm{H}$ & $\mathrm{Ti}$ \\
\hline 0.025 & 0.0185 & 0.0042 & 0.16 & 0.0103 & $\mathrm{Bal}$ \\
\hline $\begin{array}{c}\text { Yield strength } \\
\left(\mathrm{N} / \mathrm{mm}^{2}\right)\end{array}$ & $\begin{array}{c}\text { Tensile strength } \\
\left(\mathrm{N} / \mathrm{mm}^{2}\right)\end{array}$ & $\begin{array}{c}\text { Elongation } \\
(\%)\end{array}$ \\
\hline 238 & \multicolumn{2}{|c|}{324} & \multicolumn{2}{|c|}{39} \\
\hline
\end{tabular}
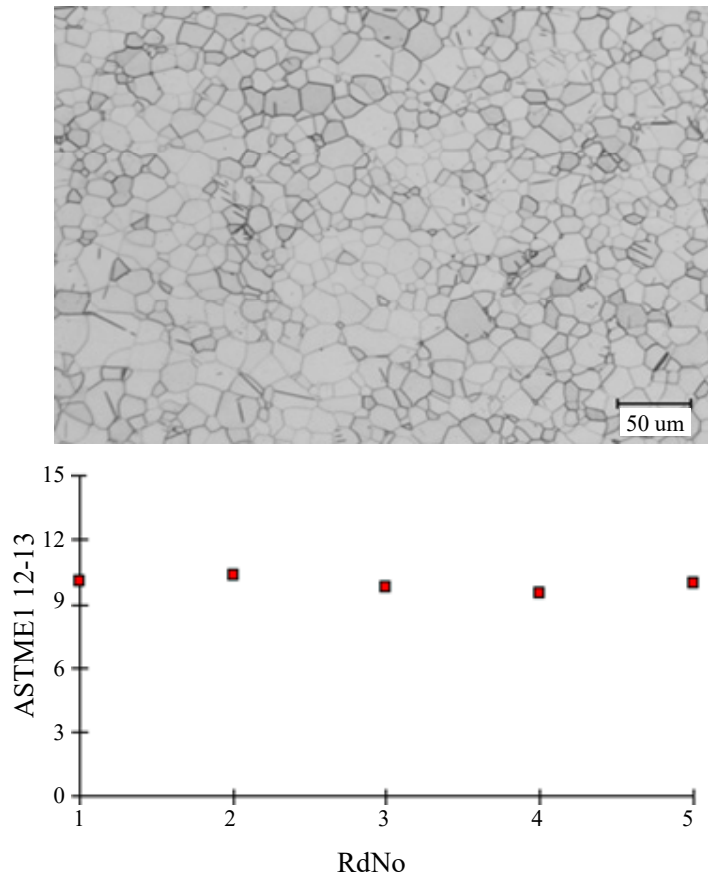

Fig. 1 Photograph showing the microstructure of the base metal

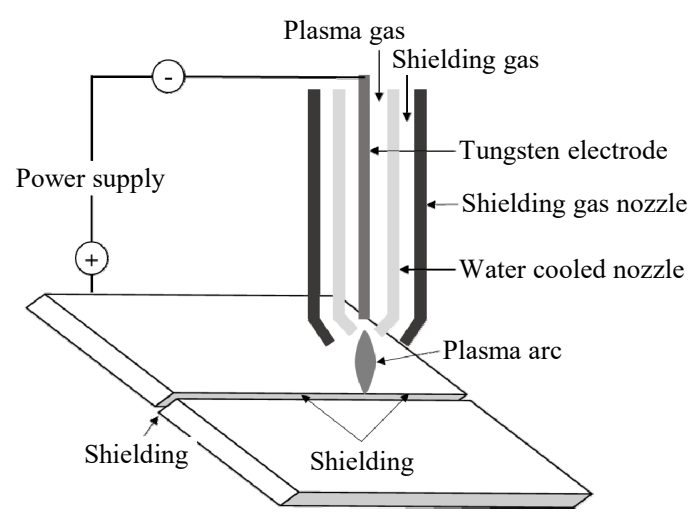

Fig. 2 Schematic diagram of the welding process

Additional lamination was required to the base material thickness of $9 \mathrm{~mm}$ for the weld zone rolling. The weld zone specimen was fabricated so that the entire height becomes $19 \mathrm{~mm}$ through plasma welding and weld bead deposition. First, plasma keyhole welding was used to minimize the heat effect at the weld zone. After the welding, the weld bead was deposited to be applied in the rolling process.

The plasma keyhole welding was performed with the I-type and without root gaps. The welding current was approximately $275 \mathrm{~A}$, the welding speed was $30 \mathrm{~cm} / \mathrm{min}$, and the heat input was around $18 \mathrm{~kJ} / \mathrm{cm}$. Here, Ar gas was additionally supplied at $25 \mathrm{~L} / \mathrm{min}$ to protect the entire weld zone from the atmosphere.

The plasma process and the CP Ti grade 1 welding rod were used to perform the build-up welding. Likewise, 


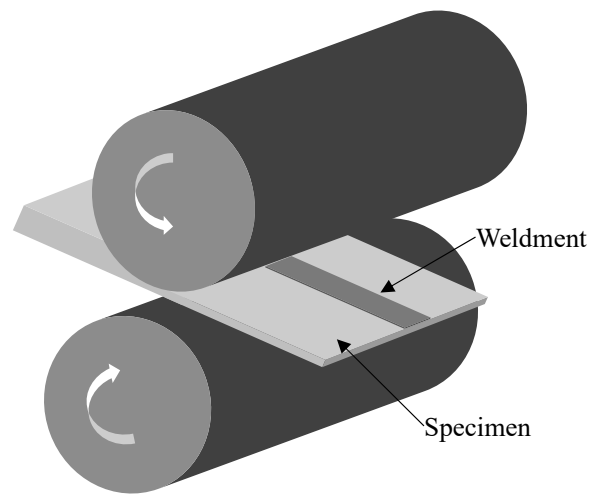

Fig. 3 Schematic diagram of rolling process used in this study

Ar gas was supplied at $12 \mathrm{~L} / \mathrm{min}$ during welding to protect the weld zone.

\subsection{Weld zone rolling}

The specimen that was fabricated under the same conditions mentioned above was used in the rolling process shown in Fig. 3. The reduction rate was adjusted to be $80 \%$ in total at room temperature for the rolling. Here, the rolling reduction per rolling frequency was $1-2 \mathrm{~mm}$, and the total rolling frequency according to the reduction rate was 20 - 30 times.

\subsection{Structural analysis and grain size measurement}

The junction was mechanically polished for analyzing the weld zone structure and measuring the grain size. Then, it was etched at room temperature for five seconds with a mixed solution of $100 \mathrm{ml}$ distilled water + $3 \mathrm{ml}$ hydrofluoric acid $+4 \mathrm{ml}$ nitric acid. A deformed structure forms in the CP Ti material even during mechanical polishing. Thus, mechanical polishing and etching were executed multiple times to remove these structures. In the microstructural observation, an optical microscope was utilized to observe the macroscopic structural transformation, and the grain size was measured according to the ASTM method at 100x magnification.

\section{Experimental Results and Discussion}

\subsection{Weld zone structure}

The specimen fabricated by plasma welding and buildup welding using this are shown in Fig. 4. As mentioned above, the height of one weld bead was $8 \mathrm{~mm}$, and the opposite side had a $2 \mathrm{~mm}$ weld bead layer.

The cross-section of the welded specimen is as provided in Fig. 5 in which twin crystals were partially found at the ferrite matrix structure in the deposited metal.

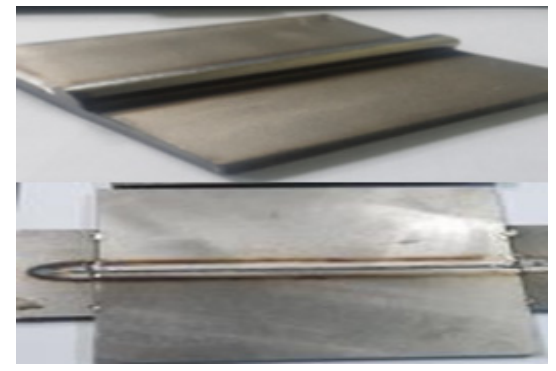

Fig. 4 Welded specimen

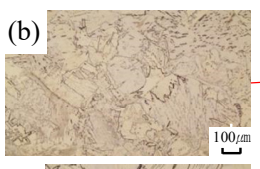

(c)

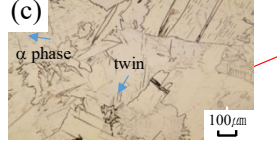

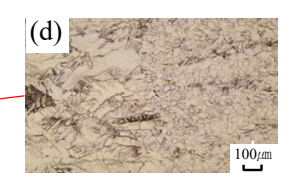

Fig. 5 Optical microstructures of specimen as welded (a) low magnification, (b) weld metal at build-up welding, (c) weld metal at keyhole welding, and (d) heat affected zone

\subsection{Results of rolling}

The welded specimen was cut to approximately 30 $\mathrm{mm}$ in width and $50 \mathrm{~mm}$ in length to perform rolling. On the side with the high weld bead layer, cracks were observed at the surface as the reduction rate increased, and the cracks were more frequent as the reduction rate increased. On the opposite side, the weld zone and the base material were simultaneously rolled as shown in Fig. 6.

\subsection{Recrystallization temperature and time cal- culation}

The Avrami equation was used to calculate the recrystallization temperature and time for refining the grain size of the rolled specimens through recrystallization annealing. The Avrami equation is shown in Equation (1) where the time at $50 \%$ transformation is represented as a variable. This equation was used to calculate the recrystallization temperature and time. For the calcu-

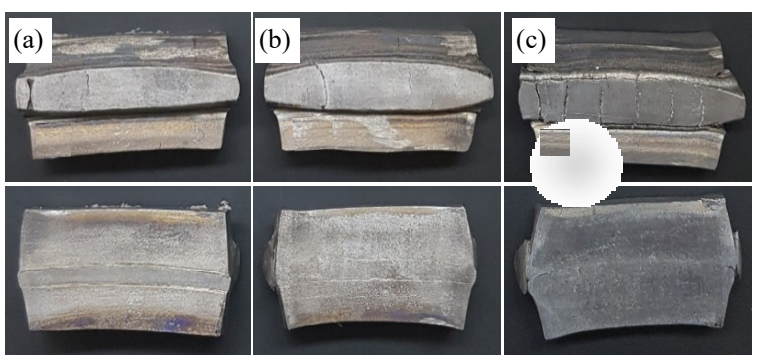

Fig. 6 Specimens after rolling, (a) reduction rate 20\%, (b) reduction rate $50 \%$, and (c) reduction rate $80 \%$ 
Table $2 \mathrm{t}_{0.5}$ values and avrami constants at varying annealing temperatures ${ }^{5)}$

\begin{tabular}{|c|c|c|c|}
\hline Annealing temperature $\left({ }^{\circ} \mathrm{C}\right)$ & 500 & 600 & 800 \\
\hline $\mathrm{n}$ & 1.0 & 1.2 & 1.0 \\
\hline $\mathrm{t}_{0.5}(\mathrm{~min})$ & 6060 & 50 & 0.2 \\
\hline
\end{tabular}

lation, the data presented in Table 2 were utilized for the Avrami exponent (n) and $t_{0.5}{ }^{3)}$.

$$
X=1-\exp \left\{-B\left(\frac{t}{t_{0.5}}\right)^{n}\right\}
$$

$\mathrm{X}$ : Area fraction of recrystallized grains

t: Annealing time

$\mathrm{t}_{0.5}$ : Time at $50 \%$ recrystallization

n: Avrami exponent

B: Constant, $\mathrm{CP} \mathrm{Ti}=0.693$

As shown in Table 2, the Avrami exponent $n$ was reported to vary according to the annealing temperature. At $\mathrm{n}=1$, the annealing time increased significantly. Therefore, the evaluation was proceeded with the lowest annealing time possible considering the circumstances of actual annealing.

Fig. 7 presents the calculation results in a graph when the Avrami exponent $\mathrm{n}$ was 1.2 and the recrystallization temperature was $500-800^{\circ} \mathrm{C}$. At $500^{\circ} \mathrm{C}$, the duration of recrystallization until completion was 46,500 minutes, which was excessively long for the actual application. At $600^{\circ} \mathrm{C}, 650^{\circ} \mathrm{C}$, and $700^{\circ} \mathrm{C}$ or higher, this time was reduced to 280 minutes, 80 minutes, and within about 10 minutes, respectively.

\subsection{Recrystallization annealing results}

In Fig. 8, which presents the microstructure images of

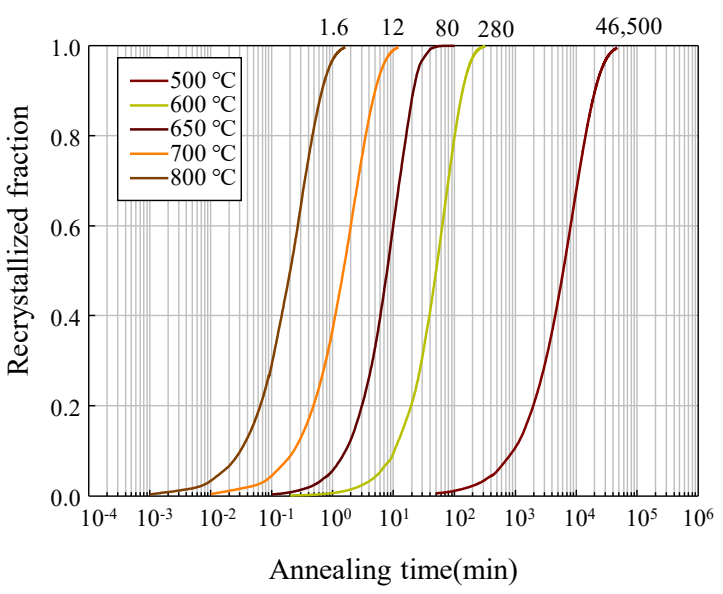

Fig. 7 Calculation results of recrystallized fraction and time at varying annealing temperatures
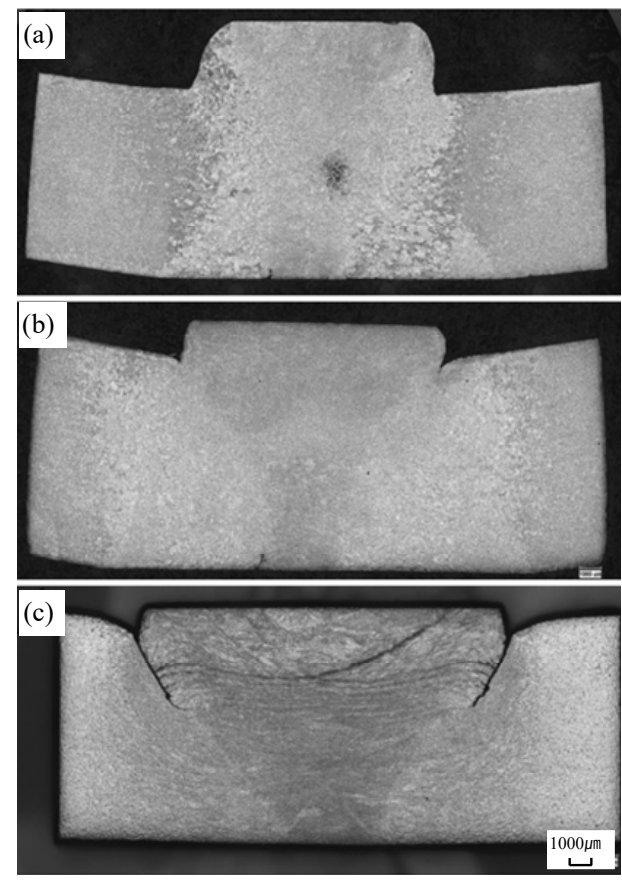

Fig. 8 Optical microstructure of welded specimens after being rolled and annealed at $650^{\circ} \mathrm{C}$, (a) reduction rate $20 \%$, (b) reduction rate $50 \%$, and (c) reduction rate $80 \%$

the rolled specimens at reduction rates of $20 \%, 50 \%$, and $80 \%$ after annealing at $650{ }^{\circ} \mathrm{C}$ for 80 minutes, recrystallization was observed in all the specimens. In addition, the deposited metal and the heat-affected zone were refined as the reduction rate increased. In the specimen with a reduction rate of $80 \%$, the microstructures between the base material and weld zone were indistinguishable.

The measurement results of the rolled and annealed specimen grain size showed that the grain size became finer as the reduction rate increased, as shown in Fig. 9

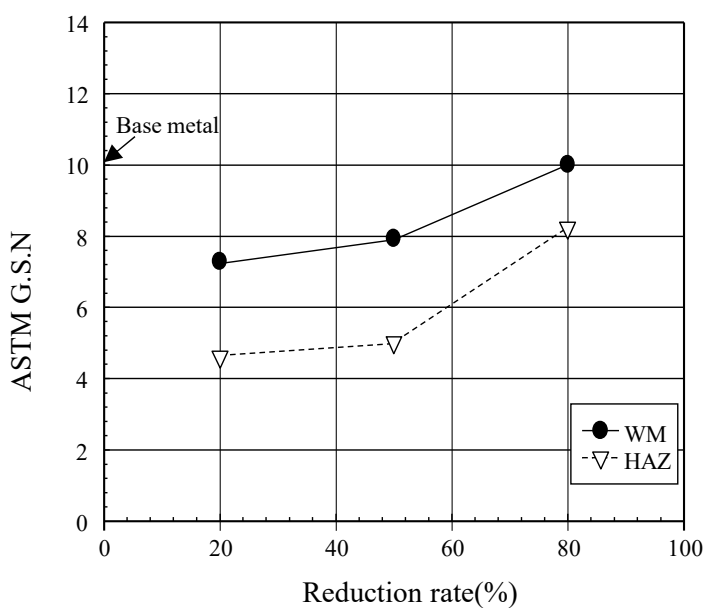

Fig. 9 Measurement results of grain size against reduction rate 

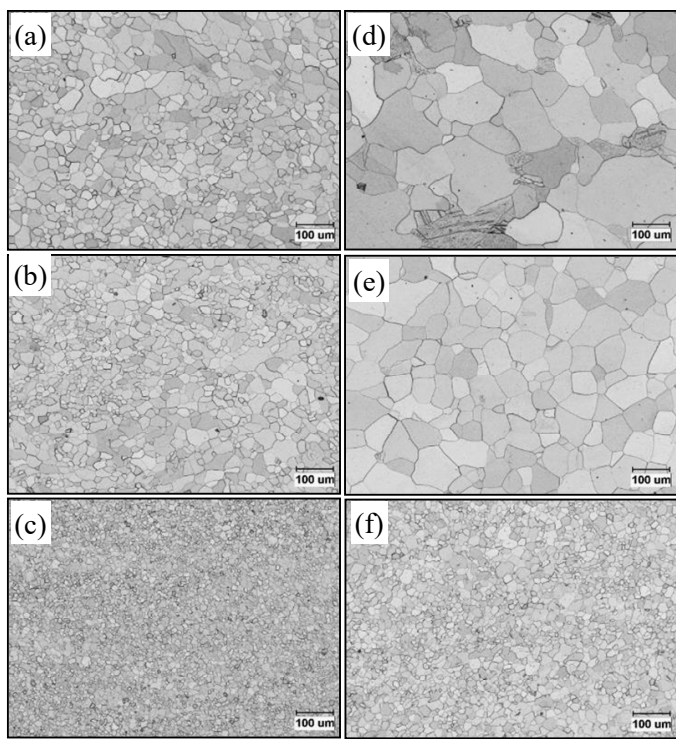

Fig. 10 Optical microstructures of the specimen as heat treated: (a) reduction rate $20 \%$ at weld metal, (b) reduction rate $50 \%$ at weld metal, (c) reduction rate $80 \%$ at weld metal, (d) reduction rate $20 \%$ at $\mathrm{HAZ}$, (e) reduction rate $50 \%$ at $\mathrm{HAZ}$, and (f) reduction rate $80 \%$ at $\mathrm{HAZ}$

and 10 . When the reduction rate was $20 \%$, the grain size of the deposited metal was about 7.3 ASTM, but it was 9.7 after the reduction rate increased to $80 \%$, which was a similar grain size to the base material. This was considered as the amount of transformation for recrystallization increasing as the reduction rate increased and the increased accumulated energy contributing to the grain size refining.

Meanwhile, the grain sizes at the heat-affected zone and the deposited metal vary, which was considered to be relevant to the laminated bead layer form. As shown in Fig. 8, the rolling force was concentrated towards the downward direction at the thick center of the weld zone bead layer. This was considered to have occurred from no rolling force being directly delivered to the heat-affected zone due to the morphological properties of the weld zone. Therefore, it was determined that the weld bead layer form must be considered to reduce the microstructural variation between the deposited metal and the heat-affected zone.

\section{Conclusions}

The following results were drawn by rolling and recrystallization annealing the weld zone of the Ti cathode drum for electrolytic copper foil fabrication.
1) A specimen was fabricated by plasma welding the CP Ti material. A specimen that formed $8 \mathrm{~mm}$ and $2 \mathrm{~mm}$ weld bead layers at the top and bottom, respectively, was fabricated for the rolling.

2) The results of rolling the welded specimens showed that cracks were generated at the side where the weld bead layer height was $8 \mathrm{~mm}$, while cracks were absent at the side with the weld bead layer height of $2 \mathrm{~mm}$ when rolling until $80 \%$.

3) The Avrami equation was used to calculate the recrystallization temperature and time and determine the recrystallization condition. Using the results, the annealing experiment was proceeded at $650^{\circ} \mathrm{C}$ for 80 minutes after which recrystallization was completed. As the reduction rate increased, a decrease in the grain size variation between the deposited metal and base material was observed.

\section{Acknowledgement}

This study was funded by the government (Ministry of Trade, Industry, and Energy) in 2020 and supported by the Materials/Parts Technology Development Program of the Korea Evaluation Institute of Industrial Technology (20010658).

ORCID: Byoung-Hyun Yoon: http://orcid.org/0000-0003-4683-7888 ORCID: Ji-Yeon Shim: https:/orcid.org/0000-0002-2825-9423 ORCID: Bong-Yong Kang: https://orcid.org/0000-0002-7826-9873

\section{References}

1. D. S. Kang and K. J. Lee, Recent R\&D status on friction stir welding of Ti and its alloys, J. Weld. Join. 33(2) (2015) 1-7. https://doi.org/10.5781/JWJ. 2015. 33.2.1

2. J. O. Moon and S. J. Park, An Investigation on the Microstructure Evolution and Tensile Property in the Weld Heat-Affected Zone of Austenitic FeMnAlC Lightweight Steels, J. Weld. Join. 35(1) (2017) 9-15. https://doi.org/10.5781/JWJ.2017.35.1.9

3. M. J. Tan, Dynamic Recrystallization in Commercially Pure Titanium, J. Achiev. Mater. Manuf. Eng. 18 (2016) 183-186. https://doi.org/10.5604/01.3001.0014.6774

4. M. Hayashi, H. Yoshimura, M. Ishii, and H. Harada, Recrystallization behavior of Commercially Pure Titanium during Hot Rolling, Nippon Steel Tech. 62 (1994) 64-68.

5. A. M. Trump and Ph. D. thesis, Recrystallization and Grain Growth Kinetics in Binary Alpha Titanium Aluminium Alloys, University of Michigan, USA (2017) 109. 


\title{
압연에 의한 $\mathrm{CP} \mathrm{Ti}$ 용접부 재결정 거동 연구
}

\section{Recrystallization Behavior of CP Ti Welds by Rolling}

\author{
윤 병 현*심 지 연** ·강 봉 용** \\ *충남대학교 급속응고신소재연구소 \\ **한국생산기술연구원 전북지역본부
}

\section{1. 서 론}

전해동박은 전기도금 공정으로 제조되는 얇은 구리 박막소재로 주로 $\mathrm{TV}, \mathrm{PC}$, 스마트폰 등 전자제품의 인 쇄회로기판에서 전기신호를 전달하는 회로소재로 사용 이 된다. 최근에는 모바일 IT, 전기자동차 등에서 필수 적으로 적용되는 리튬이온전지의 음극집전체 소재로도 수요가 확대되고 있는 소재이다. 이러한 전해 동박은 음극(티타늄), 양극(티타늄) 및 부스 바(구리)로 구성 된 제조설비를 이용한 전기도금법으로 제조하는데, 그 공정은 고순도의 구리 $(\mathrm{Cu})$ 를 황산용액에 녹여 동박 제 조를 위한 전해액(황산구리용액)을 만들고 전해조에서 황산구리용액으로부터 구리 이온을 대형 Ti Drum(음 극전극)에 전착시킨 후 박리하여 Roll제품으로 생산한다.

전착드럼 소재는 내부식성, 경량성 및 박리성 등을 고려하여 $\mathrm{CP} \mathrm{Ti}$ 소재를 사용하는데, 드럼 형태로 가공 하기 위해서는 용접이 필수적이다. 따라서 모재와 용 접부의 미세조직적 차이가 발생하게 되면 동박 표면 에 전사되어 품질불량을 초래하므로 용접부의 조직 이 모재조직과 유사하도록 조직 제어가 필요하다.

$\mathrm{Kang}^{1)}$ 등에 의하면 $\mathrm{CP} \mathrm{Ti}$ 소재의 마찰교반접합시 접합공정이 $\beta$-변태온도 이하에서 이루어지기 때문에 달성되었기 때문에 $\mathrm{CP}$ Ti에서는 상 변형이 발생하지 않았다고 보고하고 있으며, Ti-6Al-4V 합금에서는 공 정 온도가 $\beta$-변태 온도 이상에 도달하여 상변태가 발 생한다고 보고하고 있다. $\mathrm{Moon}^{2)}$ 등에 의하면 $\mathrm{Nb}, \mathrm{V}$ 를 첨가한 오스테나이트계 $\mathrm{Fe}-30 \mathrm{Mn}-9 \mathrm{Al}-0.9 \mathrm{C}(\mathrm{wt} \%$ ) 경량철강의 용접에서 $\mathrm{MC}(\mathrm{M}: \mathrm{V}$ and/or $\mathrm{Nb})$ 탄화물 이 결정립계 및 입내에 석출되어 열영향부에서 결정립 성장 억제 효과가 있었다고 보고하고 있다.

$\mathrm{Tan}^{3)}$ 등은 $\mathrm{CP} \mathrm{Ti}$ 소재를 $600^{\circ} \mathrm{C} \sim 800^{\circ} \mathrm{C}$ 범위에서 열간압연을 실시한 후 공냉을 한 결과, 결정립이 미세화 되는 재결정 거동을 관찰한 바 있으며, Hayashi ${ }^{4}$ 등도 $600^{\circ} \mathrm{C} \sim 800^{\circ} \mathrm{C}$ 범위에서 $\mathrm{CP} \mathrm{Ti}$ 소재를 압하율 변화 에 따라 열간압연을 실시한 결과, 압연시 발생한 소성 가공의 영향으로 쌍정이 형성되는 등의 압연조직의 변 화가 보이고 냉각하는 과정에서 재결정되어 조직이 미 세해진다고 보고하고 있으며, 온도 및 압하율에 따라 정 적 재결정현상으로 조직이 변화하였다고 보고하고 있다.

본 연구에서는 용접부의 크기를 최소화 할 수 있는 저입열 용접공정을 이용하고 용접부 조직을 소성가공 및 재결정 열처리를 통하여 결정립도 변화를 연구하고 자 하였다.

\section{2. 사용 재료 및 실험 방법}

\section{1 사용 재료}

본 실험에 사용된 소재는 두께 $9 \mathrm{~mm}$ 의 $\mathrm{CP} \mathrm{Ti}$ grade 1 소재로 화학적 성분 및 기계적 성질을 분석한 결과 를 Table 1 에 나타내었다. $\mathrm{Fe}$ 가 $0.025 \mathrm{wt} \%$ 함유되 어 있는 $\mathrm{Gr} .1$ 소재로 인장강도는 $324 \mathrm{MPa}$, 연신율은 $39 \%$ 이었다.

Fig. 1 은 본 소재의 미세조직을 보여주는 사진으로 결 정립도 측정 결과 ASTM No. 9.9 정도인 것으로 분석 되었다.

\section{2 용접 공정}

$\mathrm{Ti}$ 소재의 용접은 두 부분으로 나누어 진행하였다.

Table 1 The materials used in this study

$(\mathrm{wt} \%)$

\begin{tabular}{|c|c|c|c|c|c|}
\hline $\mathrm{Fe}$ & $\mathrm{C}$ & $\mathrm{N}$ & $\mathrm{O}$ & $\mathrm{H}$ & $\mathrm{Ti}$ \\
\hline 0.025 & 0.0185 & 0.0042 & 0.16 & 0.0103 & $\mathrm{Bal}$ \\
\hline $\begin{array}{c}\text { Yield strength } \\
\left(\mathrm{N} / \mathrm{mm}^{2}\right)\end{array}$ & $\begin{array}{c}\text { Tensile strength } \\
\left(\mathrm{N} / \mathrm{mm}^{2}\right)\end{array}$ & $\begin{array}{c}\text { Elongation } \\
(\%)\end{array}$ \\
\hline 238 & 324 & \multicolumn{2}{|c|}{39} \\
\hline
\end{tabular}



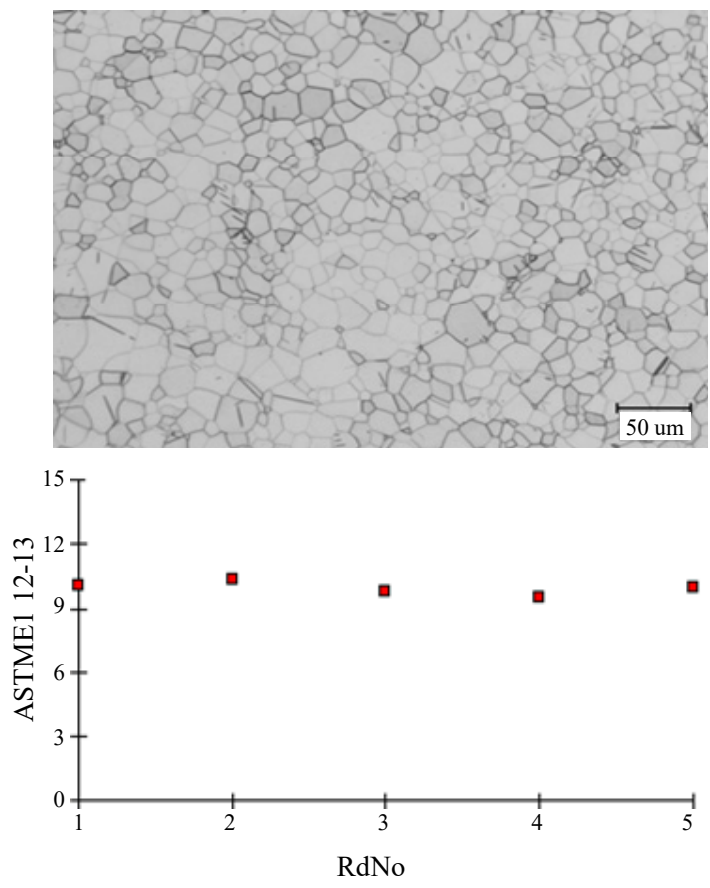

Fig. 1 Photograph showing the microstructure of the base metal

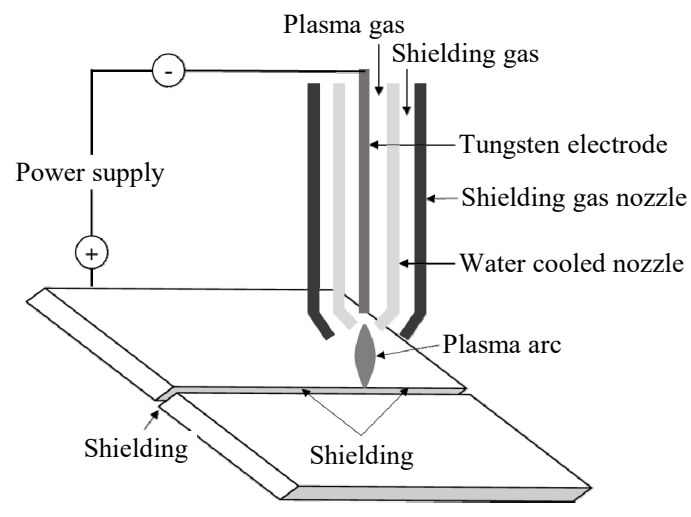

Fig. 2 Schematic diagram of the welding process

용접부 압연을 위해서는 모재 두께 $9 \mathrm{~mm}$ 이외에 추가적 인 적층이 필요하였으며 플라즈마 용접과 용접 비드 적 층을 통해 전체 높이를 $19 \mathrm{~mm}$ 가 되게 용접부 시편을 제작하였다. 우선 용접부의 열영향을 최소화하기 위해 플라즈마 키홀 용접을 이용하여 용접한후 그 위쪽에는 용접비드를 적층하여 압연공정에 적용하고자 하였다.

플라즈마 키홀 용접은 I형으로 root gap없이 용접하 였으며 용접전류는 약 $275 \mathrm{~A}$, 용접속도는 $30 \mathrm{~cm} / \mathrm{min}$ 로 입열량은 약 $18 \mathrm{~kJ} / \mathrm{cm}$ 이었다. 이때 용접부 전체를 대기로 부터 보호하기 위해 $\mathrm{Ar}$ 가스를 $25 \mathrm{~L} / \mathrm{min}$ 의 양 으로 추가 공급하였다.

빌드업 용접은 역시 플라즈마공정을 이용하여 $\mathrm{CP} \mathrm{Ti}$ grade 1 용접봉을 이용하여 적층용접을 실시하였다. 마

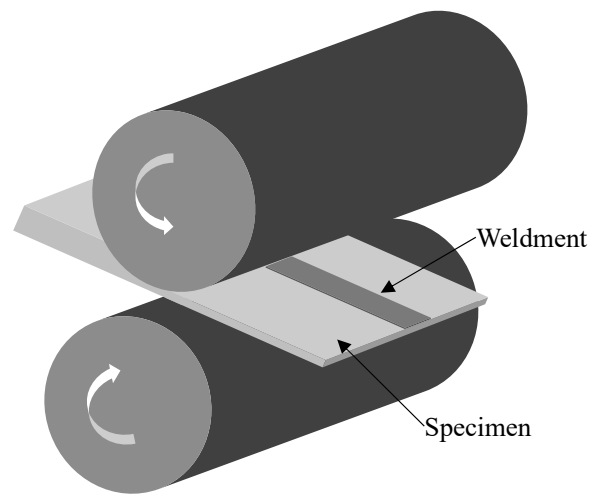

Fig. 3 Schematic diagram of rolling process used in this study

찬가지로 용접부 보호를 위해 $\mathrm{Ar}$ 가스를 약 $12 \mathrm{~L} / \mathrm{min}$ 의 양으로 공급하면서 용접을 실시하였다.

\section{3 용접부 압연}

상기와 같은 조건으로 제작된 시편을 이용하여 Fig. 3 과 같은 압연공정을 이용하여 압연을 실시하였다. 압 연은 상온에서 압하율이 총 $80 \%$ 가 되도록 하였으며, 이때 압연 횟수당 압하량 $1 \sim 2 \mathrm{~mm}$ 로 압하율에 따라 총 압연 횟수는 20 30 회 이었다.

\section{4 조직 분석 및 결정립도 측정}

용접부 조직 분석 및 결정립도 측정을 위하여 접합부 를 기계적으로 연마한 후 증류수 $100 \mathrm{ml}+$ 불산 $3 \mathrm{ml}$ + 질산 $4 \mathrm{ml}$ 의 혼합용액으로 약 5 초간 상온에서 에칭 하였다. $\mathrm{CP} \mathrm{Ti}$ 소재는 기계적 연마중에도 가공조직이 만들어지기 때문에 이러한 조직의 제거를 위하여 기계 적 연마와 에칭을 수회 실시하였다. 미세조직 관찰은 광학현미경으로 거시적 조직 변화를 관찰하였고, 결정 립도 측정은 ASTM 방법에 의하여 100 배 배율에서 측정하였다.

\section{3. 실험 결과 및 고찰}

\section{1 용접부 조직}

플라즈마 용접과 이를 이용한 적층용접으로 제작된 시편은 Fig. 4 와 같으며 전술한 바와 같이 한쪽의 용 접비드 높이는 $8 \mathrm{~mm}$, 반대쪽 면은 $2 \mathrm{~mm}$ 의 용접비드 층을 갖는 형상이다.

용접시편의 단면 형상은 Fig. 5 에 나타낸 바와 같 으며, 용착금속에서는 페라이트 기지조직에 일부 쌍정 이 발견되었다. 


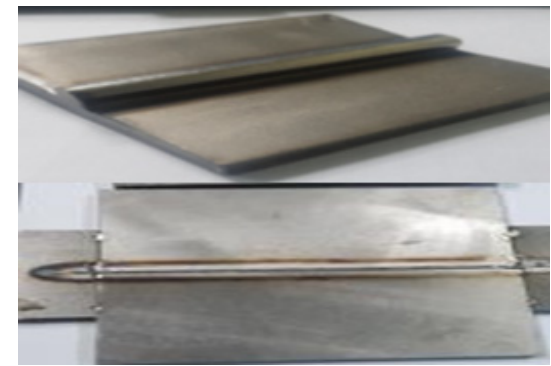

Fig. 4 Welded specimen
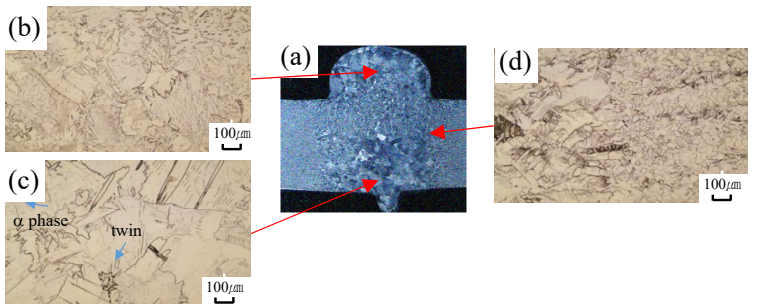

Fig. 5 Optical microstructures of specimen as welded (a) low magnification, (b) weld metal at build-up welding, (c) weld metal at keyhole welding, and (d) heat affected zone

\section{2 압연 결과}

용접된 시편을 약 폭 $30 \mathrm{~mm}$, 길이 $50 \mathrm{~mm}$ 정도로 절 단하여 압연을 실시하였다. Fig. 6은 압연 후 시편을 보여주는 사진으로 용접 비드층이 높은 면에서는 압하 율이 증가할수록 표면에 균열들이 보였으며, 압하율이 커질수록 균열은 더 많이 나타났다. 반대 면에서는 용 접부와 모재가 동시에 압연되는 형상을 보여주고 있다.

\section{3 재결정 온도 및 시간 계산}

압연이 완료된 시편을 재결정 열처리를 통하여 결정 립을 미세화하기 위해서 Avrami 방정식을 이용하여 재결정 온도와 시간을 계산하였다. 식(1) 은 변태가 $50 \%$ 완료되는 시간을 변수로 나타낸 Avrami 방정식으로 이 식을 이용하여 재결정 온도 및 시간을 계산하였다. 계산을 위한 Avrami 지수(n)과 $t_{0.5}$ 는 Table 2에 나 타낸 바와 같은 자료를 활용하였다 ${ }^{3)}$.

$$
X=1-\exp \left\{-B\left(\frac{t}{t_{0.5}}\right)^{n}\right\}
$$

Table $2 \mathrm{t}_{0.5}$ values and Avrami constants at varying annealing temperatures ${ }^{5)}$

\begin{tabular}{|c|c|c|c|}
\hline Annealing temperature $\left({ }^{\circ} \mathrm{C}\right)$ & 500 & 600 & 800 \\
\hline $\mathrm{n}$ & 1.0 & 1.2 & 1.0 \\
\hline $\mathrm{t}_{0.5}(\mathrm{~min})$ & 6060 & 50 & 0.2 \\
\hline
\end{tabular}

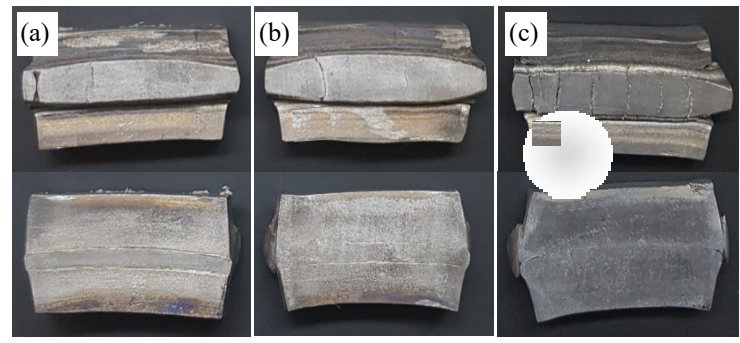

Fig. 6 Specimens after rolling: (a) reduction rate 20\%, (b) reduction rate $50 \%$, and (c) reduction rate $80 \%$

$\mathrm{X}$ : Area fraction of recrystallized grains

$\mathrm{t}$ : Annealing time

$\mathrm{t}_{0.5}$ : Time to $50 \%$ recrystallization

$\mathrm{n}$ : Avrami exponent

B: Constant, $\mathrm{CP} \mathrm{Ti}=0.693$

Table 2에 나와 있듯이 Avrami 지수, $\mathrm{n}$ 은 온도에 따라 다른 것으로 보고되고 있는데, $\mathrm{n}=1$ 로 계산을 하 면 열처리 시간이 증가하기 때문에 실제 열처리 상황을 고려하여 가능한 열처리 시간이 짧은 쪽으로 평가를 하 고자 하였다.

Fig. 7은 Avrami 지수, $\mathrm{n}=1.2$ 로 하여 재결정온도 $500^{\circ} \mathrm{C} \sim 800^{\circ} \mathrm{C}$ 범위일 때 계산 결과를 보여주는 그래 프로 $500^{\circ} \mathrm{C}$ 에서 재결정이 완료되는 시간은 약 46,500 분으로 장시간이 소요되어 실제로는 사용할 수 없는 조 건이었으며, 온도가 $600^{\circ} \mathrm{C}$ 일 때 280 분, $650^{\circ} \mathrm{C}$ 일때는 80 분으로 줄어드는 경향이 있고 $700^{\circ} \mathrm{C}$ 이상의 고온에 서는 약 10 분 이내로 줄어든다.

\section{4 재결정 열처리 결과}

Fig. 8 은 압하율이 각각 $20 \%, 50 \%, 80 \%$ 인 압 연된 시편을 $650^{\circ} \mathrm{C}$ 에서 80 분간 열처리 실험후 마크로

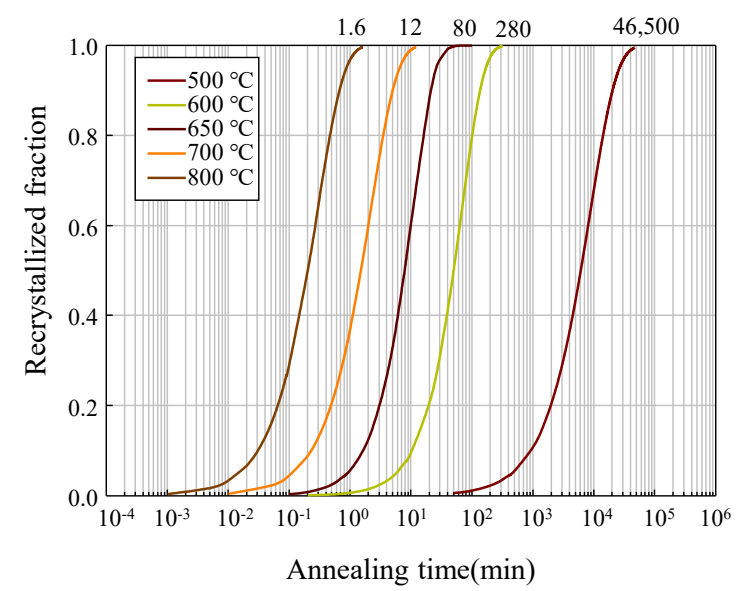

Fig. 7 Calculation results of recrystallized fraction and time at varying annealing temperatures 

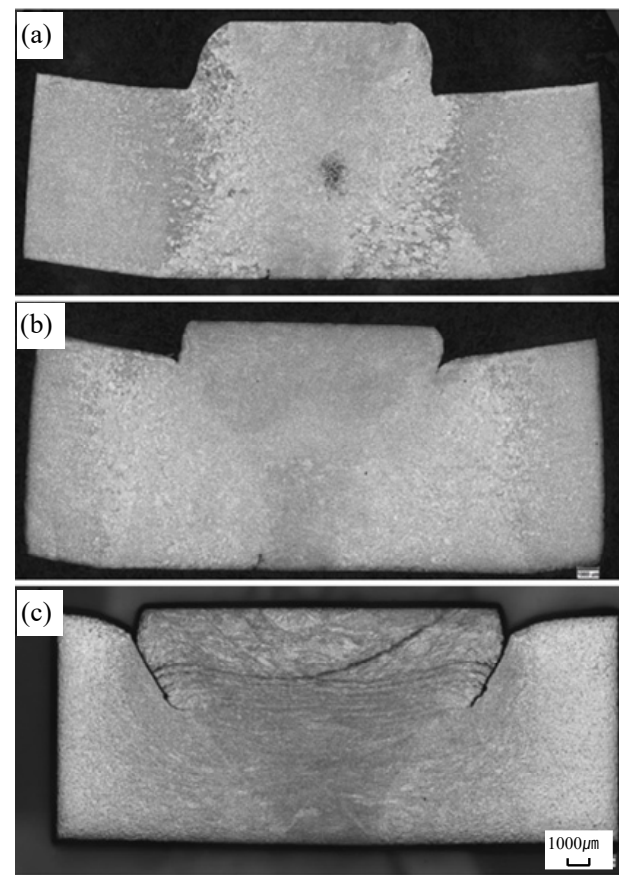

Fig. 8 Optical microstructure of welded specimens after being rolled and annealed at $6500^{\circ} \mathrm{C}$ : (a) reduction rate $20 \%$, (b) reduction rate $50 \%$, and (c) reduction rate $80 \%$

조직사진으로 시편 모두에서 재결정이 일어났음을 확인 할 수 있었으며 압하율이 증가할수록 용착금속과 열영 향부의 조직이 미세화 되는 것을 알 수 있으며 압하율 이 $80 \%$ 인 시편에서는 모재와 용접부와 구별이 되지 않을 정도로 유사한 미세조직을 가짐을 확인할 수 있었다.

압연 및 재결정 열처리된 시편의 결정립을 측정한 결 과 Fig. 9 와 10 에서 보는 것처럼 압하율이 증가하면 서 결정립도 함께 미세해 지는 것을 알 수 있다. 즉, 압 하율 $20 \%$ 일 때 용착금속의 결정립크기는 약 ASTM

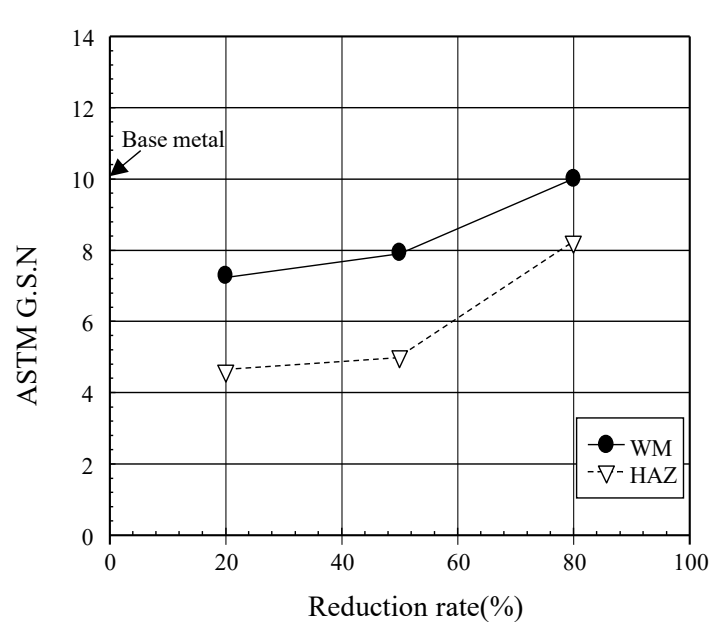

Fig. 9 Measurement results of grain size against reduction rate

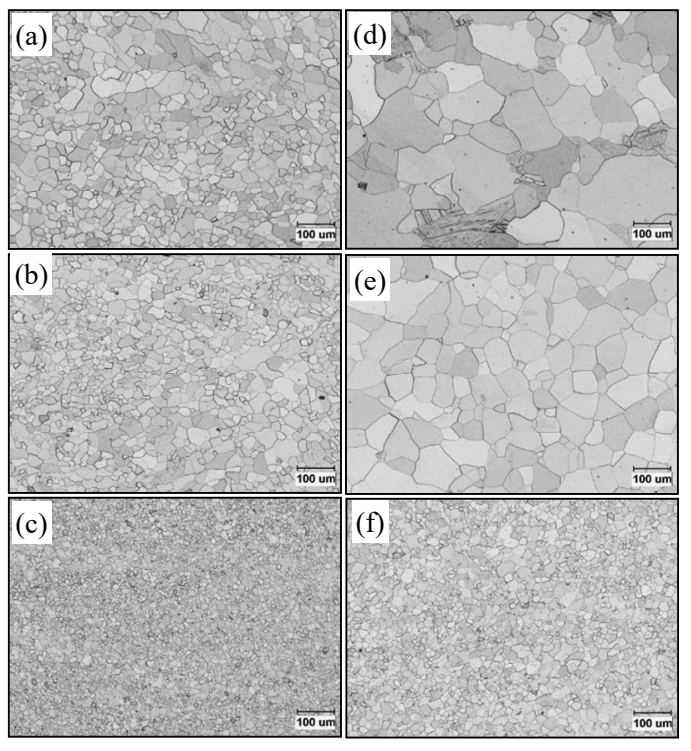

Fig. 10 Optical microstructures of the specimen as heat treated: (a) reduction rate $20 \%$ at weld metal, (b) reduction rate $50 \%$ at weld metal, (c) reduction rate $80 \%$ at weld metal, (d) reduction rate $20 \%$ at $\mathrm{HAZ}$, (e) reduction rate $50 \%$ at $\mathrm{HAZ}$, and (f) reduction rate $80 \%$ at $\mathrm{HAZ}$

번호로 7.3정도 였으나 압하율이 $80 \%$ 로 증가한 경우 에는 ASTM 번호 9.7 로 모재와 유사한 결정립 크기 를 나타내었다. 이는 압하율이 증가하면서 재결정을 위 한 소성변형량이 증가하고 이렇게 축적된 에너지가 증 가하여 결정립 미세화에 기여한 것으로 판단된다.

한편 용접열향부와 용착금속에서의 결정립크기는 차 이가 발생하는 데 이는 적층된 비드층의 형상과 관련이 있는 것으로 판단된다. Fig. 8에서처럼 용접부 비드층 의 두꺼운 중앙부에서는 압하력이 아래 방향으로 집중 적으로 전달이 되는데 용접부 형상의 특성상 용접열향 부에서는 직접적으로 압하력이 전달되지 않아 나타나는 현상으로 보인다. 따라서 용착금속과 용접열영향부의 미세조직 차이는 줄이기 위해서는 용접 비드층의 형상 도 고려해야 할 것으로 판단된다.

\section{4. 결 론}

전해동박 제조용 $\mathrm{Ti}$ 음극드럼의 용접부에 대한 압연 및 재결정열처리를 통하여 다음과 같은 결론을 도출하 였다.

1) $\mathrm{CP} \mathrm{Ti} \mathrm{소재를} \mathrm{플라즈마} \mathrm{용접으로} \mathrm{시편을} \mathrm{제작하}$ 고 압연을 위하여 상하면에 각각 $8 \mathrm{~mm}, 2 \mathrm{~mm}$ 되는 용 접비드층을 형성한 시편을 제작하였다.

2) 용접시편의 압연결과, 총 $80 \%$ 까지 압연시 압연이 진행되면서 용접비드층 높이가 $8 \mathrm{~mm}$ 인면에서는 균열이 
발생하였으나, 용접비드층 높이가 $2 \mathrm{~mm}$ 인 면에서는 균 열이 발생하지 않았다.

3) 재결정 조건을 계산하기 위하여 Avrami 방정식을 이용하여 재결정 온도 및 시간을 계산하였으며, 그 결 과를 활용한 $650^{\circ} \mathrm{C}$ 에서 80 분 열처리 실험한 결과 재 결정이 완성된 것을 확인할 수 있었으며, 압하율이 증 가할수록 용착금속과 모재와의 결정립크기 차이가 줄어 드는 것을 확인하였다.

$$
\text { 후 기 }
$$

이 논문은 2020년도 정부(산업부)의 재원으로 한국 산업기술평가관리원 소재부품기술개발사업의 지원을 받 아 수행된 연구임(20010658)

ORCID: Byoung-Hyun Yoon: http://orcid.org/0000-0003-4683-7888 ORCID: Ji-Yeon Shim: https://orcid.org/0000-0002-2825-9423 ORCID: Bong-Yong Kang: https://orcid.org/0000-0002-7826-9873

\section{References}

1. D. S. Kang and K. J. Lee, Recent R\&D status on friction stir welding of Ti and its alloys, J. Weld. Join. 33(2) (2015) 1-7.

https://doi.org/10.5781/JWJ. 2015. 33.2.1

2. J. O. Moon and S. J. Park, An Investigation on the Microstructure Evolution and Tensile Property in the Weld Heat-Affected Zone of Austenitic FeMnAlC Lightweight Steels, J. Weld. Join. 35(1) (2017) 9-15. https://doi.org/10.5781/JWJ.2017.35.1.9

3. M. J. Tan, Dynamic Recrystallization in Commercially Pure Titanium, J. Achiev. Mater. Manuf. Eng. 18 (2016) 183-186. https://doi.org/10.5604/01.3001.0014.6774

4. M. Hayashi, H. Yoshimura, M. Ishii, and H. Harada, Recrystallization behavior of Commercially Pure Titanium during Hot Rolling, Nippon Steel Tech. 62 (1994) 64-68.

5. A. M. Trump and Ph. D. thesis, Recrystallization and Grain Growth Kinetics in Binary Alpha Titanium Aluminium Alloys, University of Michigan, USA (2017) 109. 